\title{
Species Diversity and Seasonal Population Dynamics of Terrestrial Insects in Saluga and Ghazal Protected Area, Aswan, Egypt
}

\author{
Hoda M. Abdel-wahab ${ }^{1}$, Atef E. Abdel-kader ${ }^{1}$, Rahma S. Yousef ${ }^{2^{*}}$ \\ ${ }^{1}$ Zoology Department, Faculty of Science, Aswan University, Egypt \\ ${ }^{2}$ Nature Conservation Sector, Egyptian Environmental Affairs Agency, Egypt
}

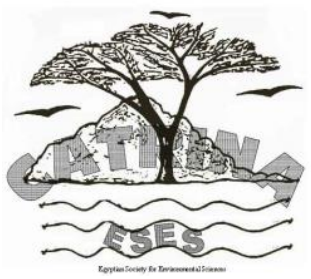

Species diversity, relative abundance and population trends of terrestrial insects were studied in Saluga and Ghazal protected area, Aswan, Egypt for the first time during one year from November 2015 to October 2016. Three different methods of survey (aerial net trap, pitfall trap and yellow sticky trap) were used in different nine sites including all habitats in the area, sandy, rocky, vegetated and aquatic area. A total of 15151 individuals of 78 species belonging to 43 families from 11 orders were recorded using the previous three methods. The net trap collected 62 species from 59 genera belonging to 32 families in 11 orders among them Lepidoptera was the most abundant order followed by Hymenoptera and Odonata and pitfall traps collected 9 species belonging to 9 genera from 4 families and 3 orders, Hymenoptera and Coleoptera were the most abundant orders, while yellow sticky traps collected 10 species belonging to 10 genera, 9 families and 5 orders, Hemiptera and Coleoptera were the most abundant orders. The study indicated that the net trap was the most effective method for monitoring the largest number of orders, families and species and the highest population number was recorded in site 3, while the lowest number was in site (9). The relation between ecological factors and abundance of the most dominant species is discussed.

Keywords: terrestrial insects, diversity, abundance, protected area, methods of survey, Saluga and Ghazal.

\section{INTRODUCTION}

Insects represent the large proportion of all biodiversity on the planet (Daly et al., 1998). They represent $85 \%$ of the world animal diversity (Groombridge, 1992). They play different roles in ecosystem function such as plants propagation (Costanza et al., 1997), increasing soil fertility (Fittkau and klinge, 1973), predation and parasitism on other organisms in order to regulate their population (Greenwood, 1987 and Daily, 1997), food source for insectivorous vertebrates, such as many birds, mammals, reptiles, and fishes (Majer, 1987), play an important role in food webs as primary consumers of plants (Banko et al., 2002), providing commercial products such as honey and silk, treatment of several illnesses (Costa Neto, 2005) and indicator for environmental changes (Gullan and Granston 2010; Belamkar and Jadesh, 2014). All this increase the support for protection of these most varied and important organisms, specially the world has large global problem of biodiversity loss and study of insects diversity remains poorly especially for the sake of biodiversity conservation (Cowling et al., 1989), so we must focus on species diversity in order to evaluate species status, this being the explicit target of conservation (Medeiros et al., 2013).

Egypt also cares about the conservation of biodiversity through its protected areas as it has 30 protectorates covering about $15 \%$ from the total area (Salama, 2010) which aim to conserve the biological, natural and cultural features, to benefit contemporary and future generations (EEAA, 2015) as the biodiversity provides support in the development of agriculture, medicine industry and basic needs of local communities in addition to new industries like ecotourism which provides high economic return (EEAA, 2009).

\section{MATERIALS AND METHODS}

\section{Study area}

Saluga and Ghazal protected area locate at distance of about $3 \mathrm{~km}$ north of Aswan Dam in the middle of Nile as it is considered a part of the first cataract islands. It is about $0.5 \mathrm{~km}^{2}$ approximately, so it is regarded as one of the smallest Egypt's 30 protectorates. It contains the remain of ancient Nile plants especially Acacia trees as it contains 4 species from 20 species of Acacia trees in the world and many other plants which have high medical importance. A total of nine sites representing the whole area of protectorate in a variety of habitat, including sandy, rocky, vegetated and aquatic area were choiced to survey, three sites of them in Ghazal Island and six sites in Saluga Island (Fig. 1).

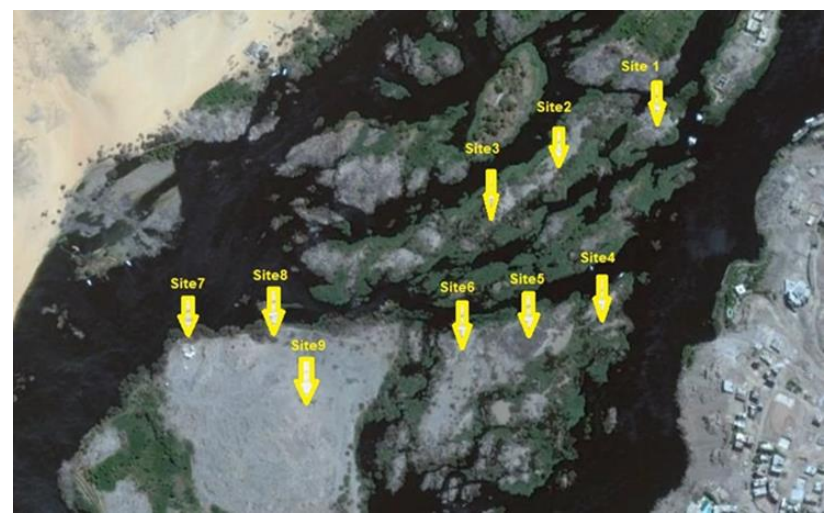

Figure (1): Map for Saluga and Ghazal protected area showing the nine sites.

\section{Ecological factors}

With regarded to geographical and natural features, this area characterized by hot and dry climate and its 
ecological factors (air temperature, humidity and wind velocity) were reported during the year of study.

\section{Methods of survey}

This work was carried out throughout one year (from November 2015 to October 2016) using different three methods

\section{Aerial net}

Standard entomological net (Borror et al., 1989) was used for collecting flying insects and those resting on vegetation (Gray and Treloar, 1933).

\section{Pitfall Trap}

Circular small white plastic cups with a $6 \mathrm{~cm}$ diameter (Schirmel et al., 2010) (27 traps, 3 traps in each site) were used to catch surface-dwelling insects.

\section{Yellow sticky trap}

Rectangular yellow plastic plates $(20 \times 30 \mathrm{~cm})(18$ traps, 2 traps in each site) were used in the survey. These plates coated with a thin layer of special sticky material, motor oil (Soliman, 2001) on one side and hanged vertically at different heights above the ground according to the high of the different plants in each site.

The insect species which monitored by using the three methods were identified in Classification Department, Plant Protection Research, Institute Agriculture Research Center, Egypt.

\section{Statistical analysis}

Data analysis was performed using SPSS program version 20 (SYSTAT statistical program). Microsoft Excel 2010 was used to construct graphs.

\section{RESULTS}

The species diversity of terrestrial insects which monitored using aerial net included 62 species, 59 genera, 32 families belonging to 11 orders and the total density of these species was 3800 individuals (Table 1).
The most dominant order was Lepidoptera included 1265 individuals represented $33.3 \%$ of the total density of all orders followed by Hymenoptera (1028 individuals) and Odonata (1000 individuals). Lycaenidae family was the most dominant family of order Lepidoptera (813 individuals) representing $64.3 \%$ of total surveyed Lepidopterous families followed by Nymiphalidae (372 individuals) which represent $29.4 \%$.T most dominant species of this order were Anthene amarah, Azanus ubaldus, Danaus chrysippus, Vanessa cardui with the total annual number of 609, 204, 222 and 150 individuals forming $48.2 \%, 16.1 \%, 17.6 \%, 11.9 \%$, respectively of the total density of all Lepidopterous species. Gilbert and Zalat (2007) also recorded different species of butterflies in different protectorates in Egypt, in St Katherine, Gebel Elba mountains, Lake Burullus, Ashtum El Gamil, Zaranik and El Ahrash protectorates and These dominant Lepidopterous species in Saluga and Ghazal protectorate as a wet land system were also recorded in another wet land system by (Akite and Olanya, 2009).

Generally, these monitored species as pollinators reached their highest peaks and greatest activity in the blooming period of their host plants especially Acacia trees (Martins et al., 2013). These species reach its highest density in the month of April (Fig. 2A) as Acasia seyal and Nilotica reach flowering peak in this month. This results agree with many authers, (Schmitt, 1983) who revealed that butterflies increases with flowering plant density, (Willson and Rathcke, 1974; Willson and Price, 1977; Schaffer and Schaffer, 1979; Davis, 1981) who observed pollinators attracted to plants with a greater number of flowers, (Grindeland et al., 2005 and Madson, 2015) who noticed increasing the number of pollinators with increasing in the flowers density and also with (Kunin, 1993; Waites and Ågren, 2004; Hegland and Boeke, 2006) who observed attraction more pollinators to abundant floral resources.

Table (1): Taxonomic list of insects monitored by aerial net in Saluga and Ghazal protectorate, Aswan during (November 2015 to October 2016).

\begin{tabular}{|c|c|c|c|c|c|}
\hline Orders & Families & Species & No. of individuals & $\%$ of species & No. of individuals of \\
\hline \multirow[t]{3}{*}{ Blattodea } & Blattidae & Blattella germanica & 6 & 100 & 6 \\
\hline & & Juloidis caillaudi & 4 & 8.5 & \\
\hline & Buprestidae & Steraspis squamosa & 10 & 21.3 & \\
\hline \multirow[t]{6}{*}{ Coleoptera } & & Sternocera castanea & 4 & 8.5 & 47 \\
\hline & Coccinellidae & Coccinella septempunctata & 1 & 2.1 & \\
\hline & Scarabaeidae & Pachnoda savignyi & 28 & 59.6 & \\
\hline & Asilidae & Stenopogon iunceus & 13 & 25.5 & \\
\hline & Bombyliidae & Aphoebantus wadensis & 4 & 7.9 & \\
\hline & Calliphoridae & Lucilia cuprina & 3 & 5.9 & \\
\hline \multirow[t]{5}{*}{ Diptera } & Muscidae & Musca domestica & 22 & 43.1 & 51 \\
\hline & & Eristalis jugorum & 3 & 5.9 & \\
\hline & Syrphidae & Eristalis taeniops & 4 & 7.9 & \\
\hline & & Eristalis quinquelineatus & 2 & 3.9 & \\
\hline & Alydidae & Xyonysius $s p$ & 4 & 11.4 & \\
\hline \multirow[t]{6}{*}{ Hemiptera } & Coccidae & Waxiella mimosae & 24 & 68.6 & 35 \\
\hline & Lygaeidae & Spilostethus pandurus & 7 & 20 & \\
\hline & Apidae & Apis Mellifica & 78 & 7.6 & \\
\hline & Aprdae & Xvlocopa pubescens & 288 & 28 & \\
\hline & Chrysididae & Chrvsis lincea & 2 & 0.2 & \\
\hline & & Chlorodynerus chloroticus & 30 & 3 & \\
\hline \multirow{7}{*}{ Hymenoptera } & Eumenidae & $\begin{array}{l}\text { Delta campaniforme } \\
\text { Eumenes maxillosus }\end{array}$ & $\begin{array}{c}10 \\
3\end{array}$ & 0.3 & \\
\hline & & Rhynchium oculatum & 2 & 0.2 & 1028 \\
\hline & Halictidae & Halictus luridipes & 4 & 0.4 & \\
\hline & Halıctidae & Halictus pollinosus & 1 & 0.1 & \\
\hline & Pompilidae & Ctenagenia vespiformis & 2 & 0.2 & \\
\hline & Scoliidae & Dielis collaris & 542 & 52.7 & \\
\hline & Sphecidae & Bembix chopardi & 28 & 2.7 & \\
\hline
\end{tabular}


Abdel-wahab et al.

\begin{tabular}{|c|c|c|c|c|c|}
\hline Orders & Families & Species & No. of individuals & $\begin{array}{l}\% \text { of species } \\
\text { from orders }\end{array}$ & $\begin{array}{c}\text { No. of individuals of } \\
\text { orders }\end{array}$ \\
\hline \multirow{6}{*}{ Hymenoptera } & \multirow{3}{*}{ Sphecidae } & Prionyx crudelis & 8 & 0.8 & \\
\hline & & Sceliphron spirifex & 8 & 0.8 & \\
\hline & & Sphex pennsylvanicus & 15 & 1.5 & \\
\hline & \multirow{3}{*}{ Vespidae } & Odynerus cyanopterus & 4 & 0.4 & \\
\hline & & Philanthus coarctatus & 2 & 0.2 & \\
\hline & & Vespa orientalis & 1 & 0.1 & \\
\hline \multirow{7}{*}{ Lepidoptera } & Geometridae & Rhodometra sacraria & 40 & 3.2 & \\
\hline & \multirow{2}{*}{ Lycaenidae } & Anthene amarah & 609 & 48.2 & \multirow{6}{*}{1265} \\
\hline & & Azanus ubaldus & 204 & 16.1 & \\
\hline & \multirow{2}{*}{ Nymiphalidae } & Danaus chrysippus & 222 & 17.6 & \\
\hline & & Vanessa cardui & 150 & 11.9 & \\
\hline & Pieridae & Catopsilia florella & 4 & 0.3 & \\
\hline & Crambidae & Nomophila noctuella & 36 & 2.9 & \\
\hline \multirow{2}{*}{ Mantodea } & \multirow[t]{2}{*}{ Mantidae } & Calidomantis savignyi & 3 & 33.3 & \multirow[t]{2}{*}{9} \\
\hline & & Sphodromantis viridis & 6 & 66.7 & \\
\hline \multirow{3}{*}{ Neuroptera } & Chrysopidae & Chrysoperla carnea & 7 & 53.9 & \multirow{3}{*}{13} \\
\hline & Myrmeleontidae & Myrmeleon formicarius & 6 & 46.2 & \\
\hline & Coenagriidae & Ischnura senegalensis & 489 & 48.9 & \\
\hline \multirow{3}{*}{ Odonata } & \multirow{4}{*}{ Libellulidae } & Brachythemis Leucostica & 17 & 1.7 & \multirow{3}{*}{1000} \\
\hline & & Crocothemis erythraea & 36 & 3.6 & \\
\hline & & Orthemis ferruginea & 453 & 45.3 & \\
\hline \multirow{12}{*}{ Orthoptera } & & Sympetrum danae & 5 & 0.5 & \multirow{12}{*}{286} \\
\hline & \multirow{10}{*}{ Acrididae } & Acrida nasuta & 63 & 22 & \\
\hline & & Acrotylus insubricus & 27 & 9.5 & \\
\hline & & Aiolopus thalassinus & 23 & 8.1 & \\
\hline & & Anacridium aegyptium & 9 & 3.2 & \\
\hline & & Calliptamus coelesyriensis & 20 & 7 & \\
\hline & & Duroniella fracta & 14 & 4.9 & \\
\hline & & Euprepocnemis plorans & 21 & 7.4 & \\
\hline & & Oxycoryphus & 25 & 8.8 & \\
\hline & & Schistocerca gregaria & 43 & 15 & \\
\hline & & Thisoicetrus littorali & 20 & 7 & \\
\hline & \multirow{3}{*}{ Lepismatidae } & Truxalis annulata & 21 & 7.4 & \\
\hline \multirow{2}{*}{$\begin{array}{l}\text { Thysanura } \\
\text { Total }\end{array}$} & & Thermobia domestica & 60 & 100 & \multirow[t]{2}{*}{60} \\
\hline & & & 3800 & & \\
\hline
\end{tabular}

According to Hymenoptera, Scoliidae and Apidae were the most abundant families including 542 and 366 individuals representing $52.7 \%$ and $35.6 \%$ from the total density of all families and Dielis collaris, Xylocopa pubescens and Apis Mellifica were the most abundant species with a total annual number of 542, 288 and 78 forming percentage of $52.7 \%, 28 \%$ and $7.6 \%$, respectively of the total species density. (Fig. 2B) illustrated that Dielis collaris started with two highest peaks during December and November. Two equal peaks for Xylocopa pubescens occurred in the months of July and August, so these results accept with (Ben Mordechai et al., 1978; Gerling et al., 1983; Sugiura, 1995; Steen and Schwarz, 2000) who illustrated that $X$. pubescens hibernate during the cold season in temperate areas but emerge on warm days in winter. The highest monthly peak of Apis Mellifica was in March. All peaks for these Hymenopterous species occurred also during the blooming period of Acacia species like (Shebl and Farag, 2015) who found Hymenopterous species associated with different plants, peaked during the flowering period of these plants. Most of these surveyed species (Xylocopa pubescens, Anthophora sp, Delta sp., Rhynchium sp., Sphex sp., Bembix sp., Dielis collarisand Vespa orientalis) were recorded in St Katherine
Protectorate, Egypt (Zalat et al., 2008).

With regarded to Odonata, It was represented by 2 families (Coenagriidae and Libellulidae) which had the same abundance with a total of 511 and 489 individuals forming $51.1 \%$ and $48.9 \%$, respectively. The most abundant species of this order were Ischnura senegalensis and Orthemis ferruginea which calculated 453 and 489 individuals with a percentage of $48.9 \%$ and $45.3 \%$, respectively of the total density of Odonata species. The same Odonatous species (Crocothemis erythraea, Ischnura sp. and Sympetrum sp.) were recorded in St Katherine Protected area (Power and Gilbert, 2014). The highest monthly peak of Ischnura senegalensis occurred during July, while the highest peak for Orthemis ferruginea was during August (Fig. $2 \mathrm{C}$ ) because the period of water level increasing in the protectorate start from the end of May to the end of August. These results are in full agreement with (Villanueva and Mohagan, 2010; Saha and Gaikwad, 2014; Rohmare et al., 2016) who reported that the diversity and abundance of Odonata species depends on some factors among them they mention the presence or absence of water bodies, size of the water bodies, flooding period.

9 species belonging to 8 genera from 4 families and 3 

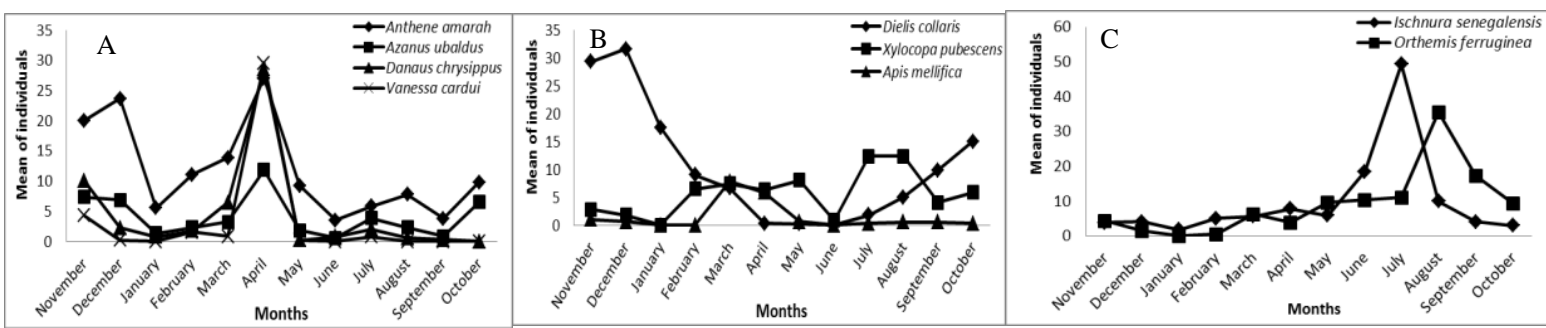

Figure (2): Population fluctuation of the most dominant species monitored by aerial net (A) Lepidopterous species, (B)

Hymenopterous species and (C) Odonatous species.

Table (2): Taxonomic list of insects monitored by pitfall traps in Saluga and Ghazal protectorate, Aswan.

\begin{tabular}{|c|c|c|c|c|c|}
\hline Order & Family & Species & No. of individuals of species & $\begin{array}{l}\% \text { of species } \\
\text { from orders }\end{array}$ & $\begin{array}{c}\text { No. of individuals } \\
\text { of orders }\end{array}$ \\
\hline \multirow{4}{*}{ Coleoptera } & Melyridae & Melyris oblonga & 1 & 0.4 & \\
\hline & Tenebrionidae & Blaps schweinfurthi & 4 & 1.5 & 264 \\
\hline & & Pimelia angulata & 228 & 86.4 & \\
\hline & & Trachyderma hispida & 31 & 11.8 & \\
\hline Hemiptera & Lygaeidae & Spilostethus pandurus & 3 & 100 & 3 \\
\hline \multirow{4}{*}{ Hymenoptera } & Formicidae & Camponotus sp. & 20 & 90.9 & \\
\hline & & Cataglyphis bombycinus & 39 & 5.9 & 662 \\
\hline & & Cataglyphis oasium & 602 & 0.2 & \\
\hline & & Crematogaster melanogaster & 1 & 3 & \\
\hline Total & & & & & 929 \\
\hline
\end{tabular}

Hymenoptera and Coleoptera were the most abundant orders with individual including 662 and 264 individuals represented $71.3 \%$ and $28.4 \%$, respectively of the total density of all orders. Formicidae was the only monitored family of Hymenoptera. The most abundant species of this family was Cataglyphis oasium (602 ants) represented $90.9 \%$ of the total species density forming its highest peak in May (Fig. 3). Different Cataglyphis species were recorded in Zaranik protected area (El-Moursy et al., 2001) and in St. Catherine protectorate (Orabi et al., 2011). The most dominant family of Coleoptera was Tenebrionidae which listed 263 individuals representing $99.6 \%$ of the total density of Coleopterous families. The most abundant Coleopterous species was Pimelia angulate ( 228 beetles) with a percentage of $86.4 \%$ of the total species density. It also recorded in Zaranik protectorate (El-moursy et al., 2001). The highest number of this species was during the months of Winter because the adults begin mating in this period, so this species formed the highest peak in December (Fig. 3) because this species in North Africa emerge in January to begin mating, synchronously with floral bloom (Schulze, 1964).

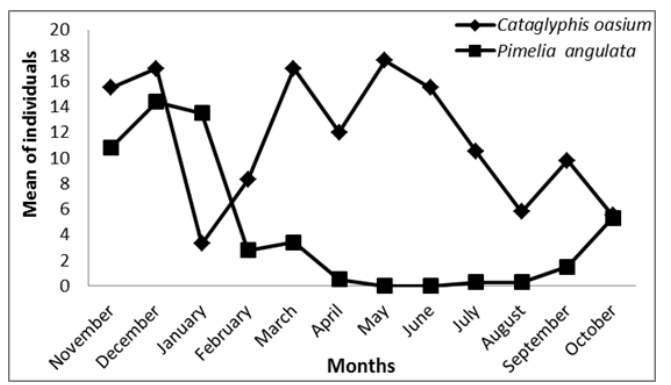

Figure (3): Population fluctuation of the most dominant species monitored by pitfall traps.
Yellow sticky traps collected 10 species belonging to 10 genera, 9 families and 5 orders with a total density of 10422 individuals (Table 3). Diptera, Hemiptera and Coleoptera were the most abundant orders which listed 8012, 1344 and 1007 individuals forming 76.9\% $12.9 \%$ and $9.7 \%$ of the total density of all orders. Culicidae was the richest Dipterous family with 7514 individuals representing $93.8 \%$ from all families density. The most abundant species was Culex $s p$. which was the only species representing to Culicidae family reaching its highest peak during August (Fig. 4). Cicadellidae was the most dominant Hemipterous family listing 1338 individuals forming $99.5 \%$ of the total families density. Batrachomorphus sp. was the most dominant Hemipterous species and the only species belonging to the Cicadellidae family forming its highest peak in October (Fig. 4). The most dominant Coleopterous family was Dermestidae with a total number of 661 individuals forming a percentage of $65.7 \%$ of the total families density. The most abundant species was found belonging to this family, Attagenus fasciatus which also recorded in in Zaranik protectorate (El-Moursy et al., 2001). It had $65.7 \%$ of the total species density and formed its highest peak in August (Fig. 4).

According to these results, the net trap was considered the most effective method for monitoring the largest number of orders, families and species in the protectorate followed by yellow sticky traps then pitfall traps. On the contrary, the yellow sticky trap method was efficient in the monitoring largest number of individuals followed by aerial net trap then pitfall trap. The highest population number was recorded in site 3 (3240 individuals) as this site included a high density of Acacia trees that distinguish the protectorate, while the lowest number (108 individuals) was in site 9 because it empty of plants. 
Abdel-wahab et al.

Table (3): Taxonomic list of insects monitored by yellow sticky traps in Saluga and Ghazal protectorate, Aswan.

\begin{tabular}{|c|c|c|c|c|c|}
\hline Order & Families & Species & $\begin{array}{c}\text { No. of } \\
\text { individuals of }\end{array}$ & $\begin{array}{l}\% \text { of species } \\
\text { from orders }\end{array}$ & $\begin{array}{c}\text { No. of } \\
\text { individuals of }\end{array}$ \\
\hline \multirow[t]{4}{*}{ Coleoptera } & Buprestidae & Anthaxia angustipennis & 8 & 0.8 & \multirow{4}{*}{1007} \\
\hline & Chrysomelidae & Bruchidius incarnatus & 204 & 20.3 & \\
\hline & Chrysomelidae & Caryedon gonagra & 134 & 13.3 & \\
\hline & Dermestidae & Attagenus fasciatus & 661 & 65.7 & \\
\hline \multirow[t]{2}{*}{ Diptera } & Chironomidae & Tanytarsus sp. & 498 & 6.2 & \multirow{2}{*}{8012} \\
\hline & Culicidae & Culex sp. & 7514 & 93.8 & \\
\hline \multirow[t]{2}{*}{ Hemiptera } & Aleyrodidae & Trialeurodes sp. & 6 & 0.5 & \multirow[t]{2}{*}{1344} \\
\hline & Cicadellidae & Batra chomorphus & 1338 & 99.5 & \\
\hline Hymenoptera & Vespidae & Odynerus cyanopterus & 56 & 100 & 56 \\
\hline Neuroptera & Chrysopidae & Chrysoperla carnea & 3 & 100 & 3 \\
\hline Total & & & & & 10422 \\
\hline
\end{tabular}

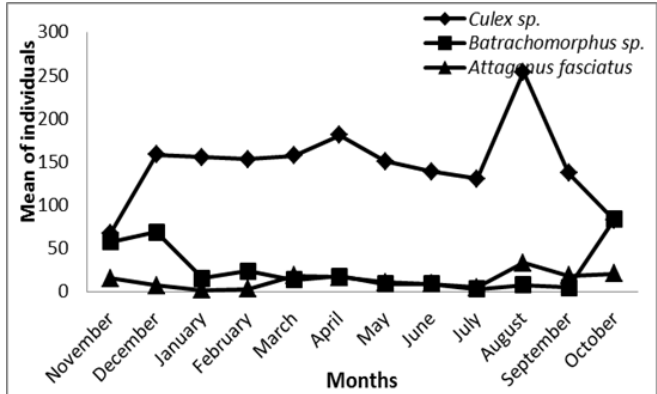

Figure (4): Population fluctuation of the most dominant species monitored by yellow sticky traps.

The association between ecological factors and abundance of the most dominant species monitored using aerial net, pitfall traps and yellow sticky traps

The reported data of ecological factor in the study area indicated that temperature ranged between $\left(44^{\circ} \mathrm{C}\right)$ in June and $\left(21.5^{\circ} \mathrm{C}\right)$ in January, the highest percent of humidity was recorded during December $(61.4 \%)$, while the lowest percent was recorded during June (20.8\%) and the mean value of wind velocity ranged from $(27.3$ $\mathrm{km} / \mathrm{h})$ in August to $(15.5 \mathrm{~km} / \mathrm{h})$ in October. By applying the correlation analysis in SPSS program between total number of species and ecological data (air temperature, humidity and wind velocity) (Table 4), it is cleared that the abundance of Xylocopa pubescens was positively correlated with temperature $(\mathrm{r}=0.597)$, Dielis collaris showed negative correlation with temperature $(\mathrm{r}=$ 0.905 ) and was in positive relation with humidity ( $\mathrm{r}=$ 0.801). The abundance of Pimelia angulata was negatively correlated with temperature $(r=-0.804)$ while it was positively correlated with humidity $(r=0.88)$

Table (4): Correlation coefficients for the association between ecological factors and the most dominant species monitored by using aerial net, pitfall traps and yellow sticky traps during the present study.

\begin{tabular}{|c|c|c|c|c|c|c|}
\hline \multirow{2}{*}{ Species } & \multicolumn{2}{|c|}{ Temperature } & \multicolumn{2}{|c|}{ Humidity } & \multicolumn{2}{|c|}{ Wind } \\
\hline & $r$ & Sig. & $\mathrm{r}$ & Sig. & $\mathrm{r}$ & Sig. \\
\hline Anthene amarah & -0.424 & NS & 0.375 & NS & - & NS \\
\hline Azanus ubaldus & -0.193 & NS & 0.165 & NS & - & NS \\
\hline Danaus chrysippus & -0.064 & NS & -0.145 & NS & 0.004 & NS \\
\hline Vanessa cardui & 0.059 & NS & -0.28 & NS & 0.092 & NS \\
\hline Dielis collaris & -0.905 & ** & 0.801 & $* *$ & - & NS \\
\hline Xylocopa pubescens & 0.597 & $*$ & -0.503 & NS & 0.363 & NS \\
\hline Apis Mellifica & 0.216 & NS & -0.447 & NS & 0.037 & NS \\
\hline Ischnura & 0.45 & NS & -0.399 & NS & 0.376 & NS \\
\hline Orthemis & -0.067 & NS & 0.245 & NS & 0.022 & NS \\
\hline Cataglyphis oasium & -0.02 & NS & 0.038 & NS & - & NS \\
\hline Pimelia angulata & -0.804 & ** & 0.88 & ** & - & NS \\
\hline Culex sp. & 0.046 & NS & -0.204 & NS & 0.446 & NS \\
\hline Batrachomorphus & -0.395 & NS & 0.575 & NS & - & NS \\
\hline Attagenus fasciatus & 0.407 & NS & -0.296 & NS & 0.094 & NS \\
\hline
\end{tabular}

\section{REFERENCES}

AKITE, P., AND A. OLANYA. 2009. Butterfly Fauna of Lake Bisina-Opeta Wetland Systems and Lake Mburo-Nakivali wetland Systems. Ecological baseline Surveys of: Lake Bisina-Opeta Wetlands System Lake Mburo-Nakivali Wetlands System, 41.

BANKO, P.C., P.T. OBOYSKI, J.W. SLOTTERBACK, S.J. DOUGILL, D.M. GOLTZ, L. JOHNSON, M.E. LAUT, AND T.C. MURRAY. 2002. Availability of Food Resources, Distribution of Invasive Species, and Conservation of A Hawaiian Bird Along A Gradient of Elevation. Journal of Biogeography, 29: 789-808.

BELAMKAR, N.V., AND M. JADESH. 2014. A Preliminary Study on Abundance and Diversity of Insect Fauna in Gulbarga District, Karnataka, India. International Journal of Science and Research (IJSR), 3(12): 1670-1675.

BEN MORDECHAI, Y., R. COHEN, D. GERLING, and E. MOSCOVITZ. 1978. The biology of Xylocopa pubescens Spinola (Hymenoptera: Anthophoridae) in Israel, Israel Journal of Entomology, 12: 107-121.

BORROR, D.J., G.A. TRIPLEHORN, AND N.F. JOHNSON. 1989. An Introduction to the Study of Insects. 6th Edition, Saunders College Publishing, Philadephia, PP. 875.

COSTA NETO, E.M. 2005. Entomotherapy, or the Medicinal Use of Insects. Journal of Ethnobiology, 25(1): 93-114.

COSTANZA, R., R. D'ARGE, R. DE GROOT, S. FARBER, M. GRASSO, B. HANNON, K. LIMBURG, S. NAEEM, R.V. O'NEILL, J. PARUELO, R.G. RASKIN, P. SUTTON, AND M. VAN DEN BELT. 1997. The Value of the World's Ecosystem Services and Natural Capital. Nature, 387: 253-260.

COWLING, R.M., G.E. GIBBS RUSSELL, M.T. HOFFMAN, AND C. HILTON-TAYLOR. 1989. Patterns of Plant Species Diversity in Southern Africa. Biotic Diversity in Southern Africa: Concepts and Conservation. Oxford University Press, Cape Town, 19-50.

DAILY, G.C. 1997. Ecosystem Services: Benefits Supplied to Human Societies by Natural Ecosystems. Issues in Ecology 2: 1-16.

DALY, H.V., J.T. DOYEN, AND A.H. PURCELL. 1998. Introduction to Insects Biology and Diversity. 
2nd Edition. Oxford University Press. pp. 187-241.

DAVIS, M.A. 1981. The Effect of Pollinators, Predators, and Energy Constraints on The Floral Ecology and Evolution of Trillium erecturn. Oecologia (Berlin), 48: 400-06.

EEAA. 2009. Egyptian state of Environment Report. Egyptian Environmental Affairs Agency; Ministry of State for Environmental Affairs, Egypt.

EEAA. 2015. Egyptian State of Environment Report. Egyptian Environmental Affairs Agency; Ministry of State for Environmental Affairs, Egypt.

EL-MOURSY, A., M. EL-HAWAGRY, M. ABDELDAYEM, AND H. FADL. 2001. Insect Diversity in Zaranik Protectorate, Northern Sinai, Egypt. Egyptian Journal of Natural History, 3, 62-80.

FITTKAU, E.J., AND H. KLINGE. 1973. On Biomass and Trophic Structure of The Central Amazonian Rain Forest Ecosystem. Biotropica, 5(1): 2-14.

GERLING, D., P.D. HURD, AND A. HEFETZ. 1983. Comparative Behavioral Biology of Two Middle East Species of Carpenter Bees (Xylocopa latreille) (Hymenoptera: Apoidea), Smithsonian contributions to zoology, 369.

GILBERT, F. AND S. ZALAT. 2007. The Butterflies of Egypt: atlas, Red Data listing and Conservation. BioMAP, EEAA, Cairo.

GRAY, H.E., AND A.E. TRELOAR. 1933. On the Enumeration of Insect Populations by The Method of Net Collection. Ecological Society of America, 14(4): 356-367.

GREENWOOD, S.R. 1987. The Role of Insects in Tropical Forest Food Webs. Ambio, 16(5), 267-271.

GRINDELAND, J.M., N. SLETVOLD, AND R.A. IMS, 2005. Effects of Floral Display Size and Plant Density on Pollinator Visitation Rate in A Natural Population of Digitalis purpurea. Functional Ecology, 19(3): 383-390.

GROOMBRIDGE, B. 1992. Global Biodiversity: Status of The Earth's Living Resources. Chapman and Hall, London. pp. 1-594.

GULLAN, P.J. AND P.S. CRANSTON. 2010. The Insects: an Outline of Entomology, 4th Edition. Wiley-Blackwell, Oxford, U.K. pp. 2-15.

HEGLAND, S.J., AND L. BOEKE. 2006. Relationships between the density and diversity of floral resources and flower visitor activity in a temperate grassland community. Ecological Entomology, 31: 532-538.

KUNIN, W.E. 1993. Sex and The Single Mustard: Population Density and Pollinator Behavior Effects On Seed-Set. Ecology, 74(7), 2145-2160.

MADSON, H. 2015. The Effect of Flowering Plant Density, Location, and Fitness on Pollination Rates. BIOS 35502-01: Practicum in Field Biology.

MAJER, J.D. 1987. The Conservation and Study of Invertebrates in Remnants of Native Vegetation. in: (Saunders, D.A., Burbidge, A.A., Arnold, G.W. and Hopkins, A.J.M. eds.) Nature Conservation: The Role of Remnants of Native Vegetation. Surrey Beatty and Sons, Sydney. 333-335.

MARTINS, D.J., S.C. COLLINS, C. CONGDON, AND N.E. PIERCE. 2013. Association Between The African Lycaenid, Anthene Usamba, and An
Obligate acacia ant, Crematogaster mimosae. Biological Journal of the Linnean Society, 109(2), 302-312.

MEDEIROS, M. J., J.A. EIBEN, W.P. HAINES, , R. KAHOLOAA, C. KING, P.D. KRUSHELNYCKY, K.N. MAGNACCA, D. RUBINOFF, F. STARR, AND K. STARR. 2013. The Importance of Insect Monitoring to Conservation Actions in Hawaii. Hawaiian Entomological Society, 45: 149-166.

ORABI, G.M., F.M. SEMIDA, M.S. ABDEL-DAYEM, M.R. SHARAF, AND S.M. ZALAT. 2011. Diversity Patterns of Ants Along An Elevation Gradient at St. Catherine Protectorate, South Sinai, Egypt: (Hymenoptera: Formicidae). Zoology in the Middle East, 54(1), 101-112.

POWER, A., AND F. GILBERT. 2014. Dragonflies and Damselflies of the St Katherine Protectorate. Egyptian Journal of Biology, 16(1): 95-100.

ROHMARE, V.B., D.M. RATHOD, AND B.M. PARASHARYA. 2016. Diversity and Population Dynamics of Odonata (insecta: Odonata) in Rice Growing Area of Central Gujarat. Journal of Biological Control, 30(3): 129-137.

SAHA, P.D., AND S.M. GAIKWAD. 2014. Diversity and Abundance of Odonata in Parks and Gardens of Pune city. J. Entomol. Zool. Stud, 2 (5): 308-316.

SALAMA, H. 2010. Environmental Awareness and Conservation of Biological Resources in Egypt: a Review of Moves to Improve the Ethical Management of our Ecosystems. Biology International, 52: 48-58.

SCHAFFER, W.M., AND M.V. SCHAFFER. 1979. The Adaptive Significance of Variations in Reproductive Habit in The Agavaceae II: Pollinator Foraging Behavior and Selection for Increased Reproductive Expenditure. Ecology, 60(5): 1051-1069.

SCHIRMEL, J., S. BUCHHOLZ, AND T. FARTMANN. 2010. Is pitfall Trapping a Valuable Sampling Method for Grassland Orthoptera?. Journal of Insect Conservation, 14(3): 289-296.

SCHMITT, J. 1983. Flowering Plant Density and Pollinator Visitation in Senecio. Oecologia, 60(1), 97-102.

SCHULZE, L. 1964. The Tenebrionidae of Southern Africa. Journal of the Entomological Society of Southern Africa, 26(2): 441-451.

SHEBL, M. A., AND M. FARAG. 2015. Bee Diversity (Hymenoptera: Apoidea) Visiting Broad Bean (Vicia faba L.) Flowers in Egypt. Zoology in the Middle East, 61(3): 256-263.

SOLIMAN, H.M. 2001. Survey of Prevailed Insect Pests in The Botanical Garden at Aswan. M.Sc. Thesis, Plant Protection Department, Faculity of Agriculture, Assiut University.

STEEN, Z., AND M.P. SCHWARZ. 2000. Nesting and Life Cycle of the Australian Green Carpenter Bees Xylocopa (Lestis) aeratus Smith and Xylocopa (Lestis) bombylans (Fabricius) (Hymenoptera: Apidae: Xylocopinae). Australian Journal of Entomology. 39 (4): 291-300.

SUGIURA. N. 1995. Burrow Construction by The Japanese Carpenter Bee, Xylocopa appendiculata 
Circumvolans Smith, for Overwintering (Hymenoptera: Anthophoridae), Journal of the Kansas Entomological Society, 68 (1): 116-119.

VILLANUEVA R.J.T., AND A. MOHAGAN. 2010. Diversity and Status of Odonata Across Vegetation Types in Mt. Hamiguitan Wildlife Sancturay, Davao Oriental. Asian Journal of Biodiversity, 1(1): 25-35.

WAITES, A.R., AND J.O.N. ÅGREN. 2004. Pollinator Visitation, Stigmatic Pollen Loads and Among Population Variation in Seed Set in Lythrum Salicaria. Journal of ecology, 92(3), 512-526.

WILLSON, M.F., AND P.W. PRICE. 1977. The
Evolution of Inflorescence Size in Asclepias (Asclepiadaceae). Evolution, 31(3): 495-511.

WILLSON, M.F., AND B.J. RATHCKE. 1974. Adaptive Design of the Floral Display in Asclepias Syriaca L. American Midland Naturalist, 92(1): 4757.

ZALAT, S., F. GILBERT, H. FADEL, M. S. ELHAWAGRY, M. SALEH, S. KAMEL, AND J. GILBERT. 2008. Biological Explorations of Sinai: Flora and Fauna of Wadi Isla and Hebran, St Katherine Protectorate, Egypt. Egyptian Journal of Natural History, 5(1): 6-15.

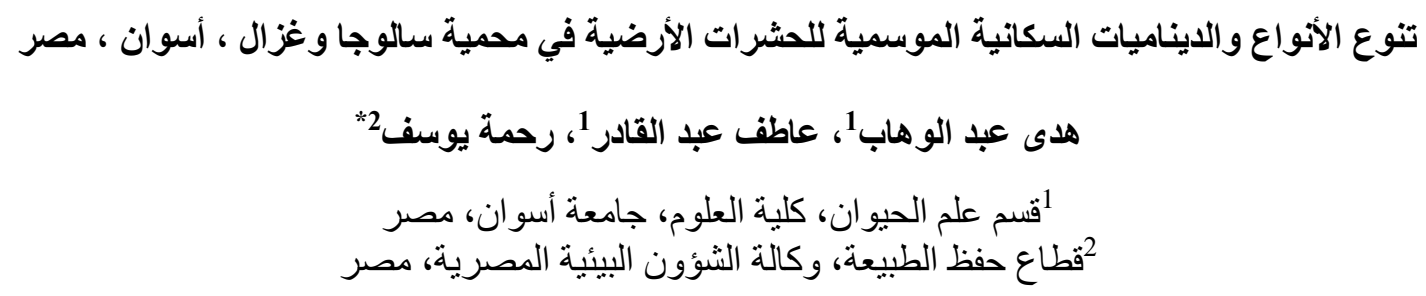

تمت در اسة تنوع الأنواع و الوفرة النسبية و الديناميكية التعدادية لأنو اع الحشرات الأرضية، في محمية سالوجا وغزال ـ أسوان مصر ، لأول مرة خلال عام واحد (نوفمبر 2015 إلى أكتوبر 2016). ولقد تم إستخدام ثلاث طرق مختلفة للرصد (مصيدة الثبكة الهو ائية، ومصايد الثر الك الأرضية و المصايد اللاصقة الصفر اء) في تسعة مو اقع مختلفة؛ تغطى جميع البيئات فى المنطقة الرملية، و الصخرية، والنباتية، و المائية. ولقد تم جمع إجمالى 15151 من الأفراد، من 78 نوعاً، تنتمي إلى 43 عائلة، من 11 1رتبة،

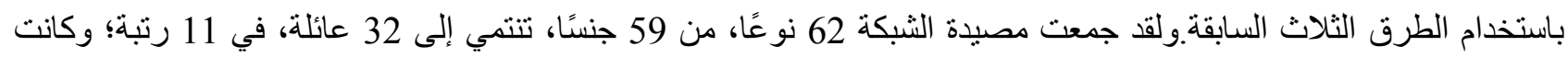
رتبة حرشفية الأجنحة، الرتبة الأكثر وفرة، تليها غشائيات الأجنحة، والرعانشات، وجمعت مصايد الثرالك الأرضية 9 أنواع،

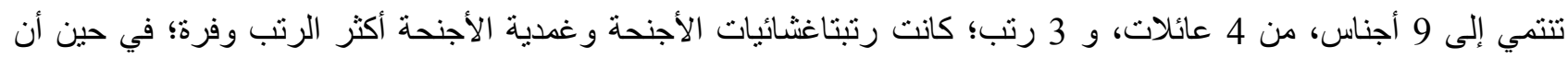
المصايد اللاصقة الصفر اء جمعت 10 أنو اع، تنتمي إلى 10 أجناس، و 9 عائلات، و 5 رتب؛ كانت رتبتا نصفية الأجنحة و غمدية الأجنحة الرتبتين الأكثر وفرة. ولقد أثشارت الدراسة الى أن مصيدة الثبكة هى الطريقة الأكثر كفاءة لرصد أكبر عدد من الرتب، و العائلات، والانواع؛ وسجل اعلى عدد للأفراد فى موقع 3، بينما كان اقل عدد فى موقع 9. واخيراً تمت مناقتنة العلاقة بين العو امل البيئية وفرة الأنو اعواع الأكثر هيمنة. 